\title{
Sustainable logistic plan for the dynamic distribution of massive mining waste
}

\author{
Marcelo Pérez, Rodrigo Estay and Víctor Encina ${ }^{1}$ \\ Department of Metallurgical Engineering and Materials, Federico Santa MaríaTechnical University, Av. España 1680, \\ Valparaíso 2340000 , Chile \\ macelo.perezc@usm.cl; rodrigo.estayh@usm.cl (corresponding author); victor.encina@usm.cl.
}

\begin{abstract}
In mining, the decrease in the quality of grades has led to further deepening of the existing deposits, determining the existence of a greater quantity of waste, increasing the probability of contact between the waste and the environment, communities and productive soils. For this reason, we propose new logistics to organize mining spaces, using multi-criteria evaluation techniques, risk assessment and the integration of spatial data within the geographic information system (GIS) to determine the optimal locations of industrial mining waste deposits. These optimal locations consider multiple factors such as geological, physical, territorial and environmental characteristics, soil quality and profitability. We also define a sustainable logistic plan for the dynamic distribution of waste using cellular automata, evaluating the interaction of a determined rhythm of waste production, with the dynamic variable of the wind. In conclusion, we have created a new methodology of systematic vision for the planning and territorial ordering of future mining projects.
\end{abstract}

Keywords: cellular automata; geographic information system; regional planning; sustainable mining; waste management.

\section{Plan logístico sustentable para la distribución dinámica de residuos masivos}

\section{Mineros}

RESUMEN

En minería, la disminución en la calidad de las leyes ha llevado a profundizar aún más los depósitos existentes, determinando la existencia de una mayor cantidad de residuos, aumentando así la probabilidad de contacto entre los residuos y el medio ambiente, las comunidades y los suelos productivos. Por este motivo, proponemos nuevas lógicas para organizar espacios mineros, empleando técnicas de evaluación multi - criterio, evaluación de riesgos y la integración de datos espaciales en el sistema de información geográfica (SIG), con el fin de determinar las ubicaciones óptimas de los depósitos de residuos industriales mineros. Estas locaciones óptimas son aquellas que en la toma de decisión considera múltiples factores del sistema inmerso, como: rentabilidad (distancia y costo), características geológicas, físicas, calidad de suelo, medioambientales, territoriales, entre otras. Asimismo, mediante el uso de autómatas celulares, definimos un plan logístico sostenible para la distribución dinámica de los residuos, evaluando la interacción de un determinado ritmo de producción de residuos, con la variable dinámica del viento. En conclusión, se crea una nueva metodología de visión sistémica para la planificación y ordenamiento territorial de futuros proyectos mineros.

Palabras clave: autómatas celulares; manejo de residuos; minería sustentable; planificación regional; Sistema de Información Geográfica. 


\section{VERSIÓN ABREVIADA EN CASTELLANO}

\section{Introducción}

Durante la última década, quizás el mayor desafío que la actividad minera ha venido presentando, recae en explicar cómo esta industria puede ser compatible con la convención mundial del concepto de desarrollo sustentable como "lograr las necesidades del presente sin comprometer las posibilidades de las generaciones futuras para lograr sus propias necesidades".

Una alternativa constructiva para aterrizar el concepto de sustentabilidad al sector minero es considerar a la minería como una parte del proceso de suministro de materiales para sostener el modo de vida occidental.

El objetivo principal de esta investigación es incorporar el estudio del ordenamiento territorial en la toma de decisiones mineras, para la planificación de los usos adecuados de los suelos y la determinación de las localizaciones óptimas de sus residuos, que conlleven a un planteamiento de una nueva lógica de cómo organizarlos y distribuirlos en el espacio bajo criterios de mitigación de riesgos y con una óptica sistémica y dinámica.

Finalmente, la principal contribución de este artículo es analizar bajo múltiples variables georreferenciadas e integradas en sistema de información geográfica, utilizando técnicas de evaluación multi - criterio (EMC; Chang et al., 2008) y proceso de jerarquías analíticas (PJA; Saaty, 1980; Siddiqui et al., 1996; Donevska et al. 2012), incorporando dinámica en el resultado, utilizando autómatas celulares ( $A C)$, es decir, cómo cada celda en la zona de estudio es afectada en el tiempo.

El estudio se lleva a cabo en la IV Región de Coquimbo en Chile, región que presenta casi el $50 \%$ de los pasivos ambientales mineros (PAM) de todo el país (Figure 1) y a la vez, posee un similar porcentaje de recursos aún no explotados.

\section{Metodología}

Las localizaciones óptimas se desprenden de lo que en esta investigación se ha denominado Índice de Riesgo (IR). El IR es un criterio numérico estimados de la evaluación multi - criterio (EMC), el cual se ha realizado considerando el método de sumatoria lineal ponderada (Barredo, 1996). En la EMC se definen datos georreferenciados reclasificados en valores de vulnerabilidad que van desde 1 a un máximo de 5.

El proceso de jerarquía analítica establece una matriz cuadrada en la cual el número de filas y columnas está definido por el número de factores a ponderar, comparando la importancia de uno sobre cada uno de los demás, de acuerdo con una escala de ponderaciones de 1/9 a 9 (Tabla 1).
Una serie de variables físicas y humanas para determinar el impacto del territorio frente a la deposición de un residuo minero masivo (Tabla 2). Estas variables cualitativas y cuantitativas fueron estandarizadas usando el proceso difuso (fuzzy process; Henríquez and Qüense. 2010).

Un automata celular (AC) se define como un sistema discreto que evoluciona en un tiempo discreto $y$ sus estados son también discretos (Adamatzky, 1994; Jiménez and Posadas, 2004). En esta investigación, se considera que el estado de la celda - botadero (si se encuentra en producción o no) cambiará si el material particulado afecta a una celda con $I R \geq 3$.7, ya sea una celda contigua o no.

Se evalúa el riesgo que implica ubicar ciertos residuos masivos mineros (botaderos de estéril, botaderos de ripios lixiviados, relaves filtrados) en un determinado sistema ambiental y territorial dentro del área de estudio, empleando las técnicas de EMC, PAJ y AC.

Las variables se agrupan en factores (Tabla 1) y se definen criterios espaciales. Estos criterios fueron evaluados en GIS, respecto al nivel de vulnerabilidad que cada una de ellas podría presentar. La forma para definir los criterios de los niveles de vulnerabilidad fue mediante revisión bibliográfica experta y entrevistas con ocho profesionales expertos de diferentes áreas (geología, minería, geografía económica, hidrología y meteorología).

Los grados de vulnerabilidad para cada factor son reclasificados en valores de 1 a 5 según el nivel de probabilidad de ocurrencia o de susceptibilidad (Figura 2). Luego, cada valor es multiplicado por el peso global obtenido del proceso de jerarquías analíticas (AHP) para cada clase (Figura 3), obteniendo un mapa de riesgo, el cual es usado como base para el desarrollo de los autómatas celulares.

Son evaluadas las ubicaciones óptimas definidas por IR < 3.7 (del mapa de riesgo). Se construye una grilla, donde cada celda tiene un área de $1 \times 1 \mathrm{~km}^{2}$ (Figure 4a)

A continuación, se define un punto específico donde se encontrará la excavación minera (punto azul en la Figura 4a), la cual tendrá definida una producción de 5,000 ton/día, de acuerdo con la mediana minería en Chile. Ese tipo de producción generaría 10,000 ton/día de desechos, los cuales serán depositados en botaderos trapezoidales, utilizando toda el área de dentro de la cada grilla.

El crecimiento de estas pilas con la interacción del viento, en diferentes intervalos de altura, va provocando propagación de material particulado fino $1<10$ $\mathrm{mm}$ ) hacia las áreas circundantes del territorio (Figura 4b).

La simulación de los autómatas celulares iterará en cada una de las celdas posibles con $I R<3.7$. El crecimiento del botadero en la celda aumentará hasta que alguno de los siguientes escenarios ocurra primero: 
- El contaminante emitido por el botadero caiga en una celda con $I R \geq 3$.7.

- El botadero alcance la altura máxima pre-definida de $120 \mathrm{~m}$.

\section{Resultados}

Se consideró un análisis sistémico del territorio bajo un escenario previo de la operación minera, con el objetivo de compararlo con el resultado final (Figura $6)$.

Las zonas más afectadas son Andacollo, Illapel y Salamanca. Indirectamente puede afectar a ciudades más grandes como La Serena y Coquimbo.

La Figura 7 muestra los resultados de la programación de $A C$, que permite definir la logística de distribución sustentable de los botaderos. Treintaisiete casos fueron seleccionados como resultados óptimos posibles. El detalle de los primeros 14 casos son mostrados en la Figura 8. En el primer caso mostrado se genera el menor impacto, de acuerdo con el valor de IR. Este valor corresponde al máximo valor de la celda que el material particulado alcanza en la simulación. Adicionalmente, se alcanza un alto volumen del botadero $\left(101,450,000 \mathrm{~m}^{3}\right)$, alcanzando una altura de $101.45 \mathrm{~m}$, pero se obtiene una distancia mayor mina - botadero.

Por otra parte, el caso 12 presenta una distancia mínima mina - botadero, un volumen de botadero similar $\left(105,000,000 \mathrm{~m}^{3}\right)$ pero con un mayor impacto (IR $=5.0$ ).

Los volúmenes anteriormente mencionados, son equivalentes a aproximadamente 46 años de producción de 10,000 ton de estéril con una densidad de 1.6 ton $/ \mathrm{m}^{3}$.

\section{Conclusiones}

- Esta es una primera aproximación a un problema complejo, correspondiente al mejor caso posible. Varios parámetros y criterios podrían ser calibrados de forma más precisa y se podrían incluir otras variables, creando un modelo más robusto.

- Los sectores del estero de Pupio, el río Choapa y Caimanes de la mina Los Pelambres, son algunos de los casos más graves en lo que a problemas socio - ambientales respecta. De acuerdo con lo anterior, los resultados muestran que estos sectores son calificados como inapropiados para localizar desechos mineros. Lo mismo ocurre con Andacollo y la operación minera Carmen de Andacollo.

- Estas incompatibilidades también se hacen presentes en ciudades como Illapel y Salamanca, coincidente con proyectos mineros futuros como mina Tres Valles y Don Gabriel.

\section{Introduction}

During the last decade, perhaps the greatest challenge that mining activity has to confront is to explain how this industry can be compatible with the global convention of the concept of sustainable development, established by the Brundtland report of the world commission on environment and development (WCED) of the United Nations (1987). The WCED defines sustainable development as "to ensure that it meets the needs of the present without compromising the ability for future generations to meet their own needs". This definition, although well evolved in the past 30 years, and consolidated in different United Nations conferences, in the mining sector, as well as in academic and corporate circles, has still not fully allayed the doubts and opinions in respect to whether the concept of sustainability is applicable or not to mining (United Nations, 1987; Echavarría, 2004). Some affirm that it is not possible, precisely because it exploits non - renewable resources, and others interpret that obtaining a favourable resolution by the competent authority, is enough to demonstrate that the mining operation is sustainable.

A constructive alternative to define sustainability in the mining sector is to consider it as a part of the process of supplying the materials needed to sustain an occidental lifestyle. We find ourselves using thousands of machines, firearms and technological instruments which allow the significant improvement in their interaction with nature and fulfill our various needs. These demands are reached if we consider the materials needed to produce them (Encina and Pérez, 2016).

Most of these raw materials have a mineral origin. Nevertheless, considering that a significant part of these materials may have organic origins, they are not found naturally ready for use. In synthesis, the realistic thing to do is to realize that society cannot "sustain" itself without the organics industry or the mineral industry, both of which have similar problems of resource use and waste production.

While this epistemological approximation toward sustainable mining helps us to comprehend and substantiate the necessity for this activity, further than the traditional justification of the economic profitability, on its own it does not achieve a model of "how to". In practice, the entire production chain is effectively more harmonious, clean and sustainable with all the environmental and territorial agents. This is accentuated even more when observing the challenges on a more local scale, such as: the variability of the commodities, which affects the metabolism of the territories when confronted with the increase and decrease of the rhythms of production; the decrease of the grades, which entails a higher quantity of waste in less time; the closeness of future untapped deposits with communities and locations; and the increase of the socio-natural risk 
generated by the interaction between the hydrometeorological threats.

The main goal of this research is to incorporate the territorial ordering study into mining decision making, for the planning of the proper uses of soil and the determination of optimal locations for waste, which involve the proposal of a new logic in organizing and distributing in the lowest criteria of the mitigation of risks with a systemic and dynamic view.

Finally, the main contribution of this article is to analyse under multiple geo-referential variables integrated within GIS, utilizing multi-criteria evaluation techniques (MCE; Chang et al., 2008), and analytical hierarchy processes (AHP; Saaty, 1980; Siddiqui et al., 1996; Donevska et al., 2012) incorporating dynamics to the results, using cellular automata (CA), i.e., how each of the cells in the study area are affected in time.

\section{Source of data}

The study takes place in the region of Coquimbo in Chile, a region which presents $50 \%$ of the mining environmental liabilities (MEL) of the entire country (Fig. 1) and at the same time, possesses a similar percent- age of untapped resources. A MEL is waste without environmental regulation.

The information used in this research comes from the spatial data infrastructure of the Ministerio de minería, medio ambiente y energía of Chile. AdditionaIly, land relief (NASA - Shuttle RadarTopography Mission-SRTM, 1 arcseg) and precipitation data (http:// www.worldclim.org/current) have been included. For the wind velocity, we downloaded the data from the wind explorer developed by the department of geophysics of the University of Chile, in the German collaboration agency GIZ (http://walker.dgf.uchile.cl/ Explorador/Eolico2/). The wind velocities were the annual average of the year 2010 at heights of 5, 10, 20, $40,50,60,80,100$ and 120 metres.

Finally, the wind rose information was downloaded from the national system information of air quality (https://sinca.mma.gob.cl/index.php/estacion/index/ id/194), considering the same year 2010 but in an average of one hour.

The process and spatial data analysis were done using ArcGis, Global Mapper and Q-Gis. The cellular automata programming and analysis were done with Matlab.
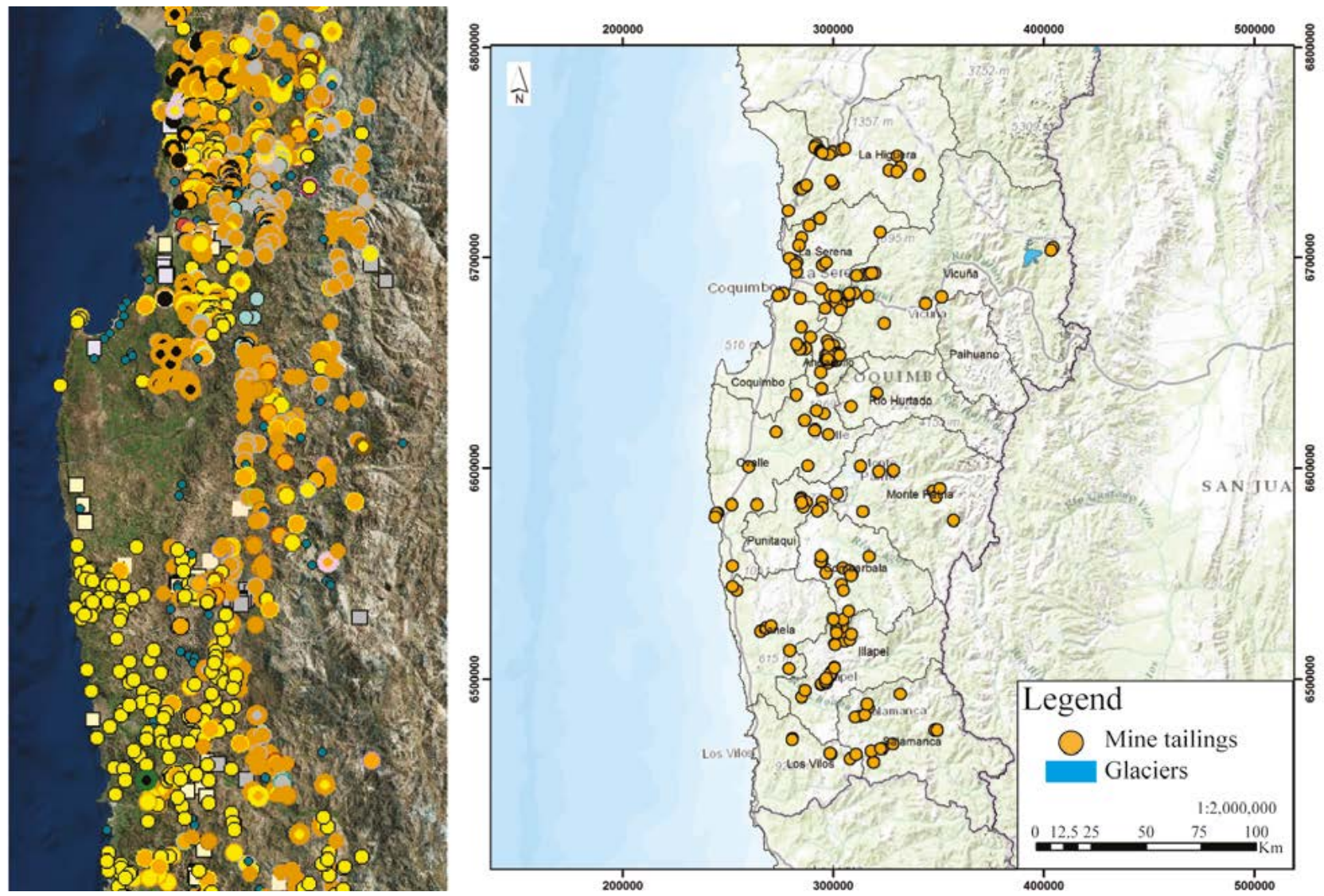

Figure 1. (Left) Location of the mining activity in the study area (infrastructure of the geospatial data, 2019). Circles and squares represent different types of mineralogy ( $\mathrm{Cu}, \mathrm{Au}, \mathrm{Ag}$, etc). (Right) Location of mine tailings (Fundación Terram, 2019).

Figura 1. (Izquierda) Ubicaciones de la actividad minera en la zona de estudio (infraestructura de datos geoespaciales, 2019). Círculo y cuadrados representan diferentes tipos de mineralogía (Cu, Au, Ag, etc). (Derecha) Ubicación de relaves mineros (Fundación Terram, 2019). 


\section{Methodology}

Optimal locations in GIS, multi-criteria evaluation and analytical hierarchy process.

The optimal locations were defined using the Risk Index (RI). The RI is a numerical criterion estimated from the multi-criteria evaluation (MCE), which was performed considering the linear weighted sum method (Barredo, 1996). In the MCE geo-referenced data is defined and reclassified in values of vulnerability ranging from 1 to 5, corresponding to the minimum and maximum vulnerability level respectively. Then, the value of each criterion is multiplied, $v_{i j^{\prime}}$ by the global weight $\left(w_{j}\right)$ of each factor $j$.

$$
r_{i}=\sum_{j=1}^{n} w_{j} v_{i j}
$$

where $r$ is the final score of the alternative $i$.

The analytical hierarchy process (Saaty, 1980, 1990) was used to determine the weights of these factors. The method establishes a square matrix in which the number of rows and columns is determined by the number of factors to weigh, comparing the importance of one over the others according to a weighing scale of $1 / 9$ to 9 (Table 1 ).

The main advantage of the multi-criteria evaluation

\begin{tabular}{|c|c|c|c|c|c|c|c|c|}
\hline \multicolumn{4}{|c|}{ Minimum impact } & Equal impact & \multicolumn{4}{|c|}{ Maximum impact } \\
\hline 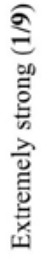 & 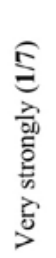 & 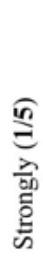 & 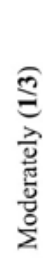 & 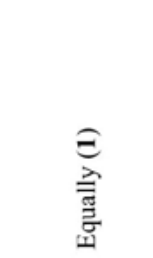 & 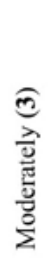 & 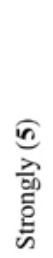 & 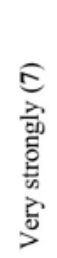 & 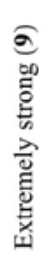 \\
\hline
\end{tabular}

Table 1. Scale of criteria values proposed by Saaty (1990) and adopted by Barredo (1996).

Tabla 1. Valores de criterio propuesto por Saaty (1990) y adaptado por Barredo (1996).

method is to be able to measure the consistency of the weights assigned by the decision makers in the matrix of comparisons. For this, the consistency reason (CR) is defined by:

$$
C R=C I / R I
$$

The value of $\mathrm{Cl}$ is expressed as:

$$
C I=\lambda_{\max }-n /(n-1)
$$

where $\lambda_{\max }$ is the value of the consistency vector and $n$ is the number of classes of the comparison matrix. Saaty (1990) proposed that the value of CR should not be greater than $10 \%$.

Previously, a series of physical and human variables were proposed to determine the impact of the territory from the disposal of a massive mineral waste (Table 2). These qualitative and quantitative variables were standardized using the fuzzy process (Henríquez and Qüense. 2010).

\section{Cellular Automatons (CA)}

A cellular automata is defined as a discrete system which evolved in a discrete time and space and their states are also discrete (Adamatzky, 1994; Jiménez and Posadas, 2004). In the traditional use of CA, the state of each element depends on the previous state of their neighbouring elements, according to a combination of simple rules of transition but when combined are capable of demonstrating complex behaviour (Benavente, 2006). In this study, we have changed this definition of the behaviour of the $\mathrm{CA}$, considering that the state of the dump-cell (in production or not) will change if it affects a restricted cell $(R I \geq 3.7)$ with particulate material, even if it is a contiguous cell or not.

The dynamics of the automaton responds to the following general rules:

- a time step of $\Delta t=1 \mathrm{hr}$, which is the resolution of the model,

- a height of the dump waste which will grow according to the production rate, with a maximum value of $120 \mathrm{~m}$,

- a prioritization in the selection of the "next cell", considering the minimum distance from the origin of the mining to the cell of evaluation and

- when the radius in which pollution may impact a cell with an $\mathrm{RI} \geq 3.7$, the automata take another location, successively repeating within the optimal possible options.

\section{Methodological design}

The risk involved by locating massive mining waste (sterile waste, leachated waste, filtered tailings) is evaluated in a determined environmental and territorial system within the area studied, using the MEC technique, the AHP and CA.

The variables are grouped into factors (Table 1) and special criterion are defined. This criterion were evaluated in GIS, with respect to the level of vulnerability which each could present. The way that the criteria of the levels of vulnerability were defined was through expert bibliographical revision and interviews with eight professional experts from different areas (geology, mining, economic geography, hydrology and meteorology).

The degrees of vulnerability for each factor were reclassified in values of 1 to 5 according to the level of susceptibility (Fig. 2). Each value is multiplied by the global weight obtained through the AHP for each class (Fig. 3), thus obtaining a risk map which is sub- 
Pérez, M., et al, 2021. Sustainable logistic plan for the dynamic distribution of massive mining waste..., 132 (4): $509-521$

\begin{tabular}{|c|c|c|c|}
\hline Factor & Variable & $\begin{array}{c}\text { Source of } \\
\text { information }\end{array}$ & Description of Criteria of Vulnerability \\
\hline \multirow{3}{*}{ Quality of soil } & 1. Erodability & $\begin{array}{l}\text { SINIA (National } \\
\text { Environmental } \\
\text { Information System) }\end{array}$ & $\begin{array}{l}\text { Degrees according to levels from very high, } \\
\text { high, moderate, low, and very low or not } \\
\text { present. }\end{array}$ \\
\hline & 2. Drought & $\begin{array}{l}\text { SINIA (National } \\
\text { Environmental } \\
\text { Information System) }\end{array}$ & $\begin{array}{l}\text { Classification according to very severe, } \\
\text { severe, moderate, minor and null. }\end{array}$ \\
\hline & 3. Level of permiability & $\begin{array}{l}\text { IDE Chile (Ministry of } \\
\text { National Assets)- } \\
\text { Gcological }\end{array}$ & $\begin{array}{l}\text { Expert criteria, classification of types of rock: } \\
\text { sedimentary, metamorphic, plutonic, igneous. }\end{array}$ \\
\hline \multirow{2}{*}{$\begin{array}{l}\text { Stability of the } \\
\text { soil }\end{array}$} & 4. Geological faults & $\begin{array}{l}\text { IDE Sernageomin } \\
\text { (Ministry of Mining): } \\
\text { cartographic } \\
\text { digititalization of } \\
\text { active faults }\end{array}$ & $\begin{array}{l}\text { Function monotonically }(<50 \mathrm{~m}, 51-100 \mathrm{~m} \text {, } \\
101-150 \mathrm{~m}, 151-200 \mathrm{~m} \mathrm{y}>250 \mathrm{~m}) \text { Expert } \\
\text { criteria. }\end{array}$ \\
\hline & 5. Ravines & $\begin{array}{l}\text { MDT - Topographic } \\
\text { Sensor Radar of } \\
\text { NASA. }\end{array}$ & $\begin{array}{l}\text { Function monotonically }(<250 \mathrm{~m}, 201-500 \\
\mathrm{m}, 401-750 \mathrm{~m}, 800-1000 \mathrm{~m} \mathrm{y}>1000 \mathrm{~m}) \text {. } \\
\text { Based on the maximum area in front of the } \\
\text { flood of } 2015 \text {. }\end{array}$ \\
\hline
\end{tabular}

\begin{tabular}{|c|c|c|c|}
\hline \multirow{4}{*}{$\begin{array}{l}\text { Superficial } \\
\text { waters }\end{array}$} & 6. Rivers and tidelands & $\begin{array}{l}\text { IDE Chile (Ministry of } \\
\text { National Assets) }\end{array}$ & \multirow{3}{*}{$\begin{array}{l}\text { Function monotonically }(<1 \mathrm{~km}, 2-4 \mathrm{~km}, 5-7 \\
\mathrm{km}, 8-10 \mathrm{~km} \text { y }>10 \mathrm{~km}) \text {. Expert criteria } \\
\text { bibliographical revision. }\end{array}$} \\
\hline & 7. Wetlands & $\begin{array}{l}\text { SINIA (National } \\
\text { Environmental } \\
\text { Information System) }\end{array}$ & \\
\hline & 8. Lagoons and lakes & $\begin{array}{l}\text { SINIA (National } \\
\text { Environmental } \\
\text { Information System) }\end{array}$ & \\
\hline & 9. Precripitations & $\begin{array}{l}\text { Worl Clim: annual } \\
\text { average }\end{array}$ & $\begin{array}{l}\text { Function monotonically }(201-300 \mathrm{~mm}, 151- \\
200 \mathrm{~mm}, 101-150 \mathrm{~mm}, 26-100 \mathrm{~mm} \text { y } 10-25 \\
\mathrm{~mm}) \text {. Expert criteria, bibliographical revision. }\end{array}$ \\
\hline \multirow{4}{*}{$\begin{array}{l}\text { Value of the } \\
\text { landscape }\end{array}$} & 10. Tourist circuits & \multirow{4}{*}{$\begin{array}{l}\text { SINIA (National } \\
\text { Environmental } \\
\text { Information System) }\end{array}$} & \multirow{4}{*}{$\begin{array}{l}\text { Function monotonically }(<1 \mathrm{~km}, 2-4 \mathrm{~km}, 5-7 \\
\mathrm{km}, 8-10 \mathrm{~km} \text { y }>10 \mathrm{~km}) \text {. Expert criteria } \\
\text { bibliographical revision. }\end{array}$} \\
\hline & 11. Natural monuments & & \\
\hline & $\begin{array}{l}\text { 12. Protected national } \\
\text { resources }\end{array}$ & & \\
\hline & 13. National parks & & \\
\hline
\end{tabular}


14. Private conservation innitiatives

15. Accesibility from populated areas

Human accesibility to possible waste

16. Educational establishments
SINIA (National

Environmental

Information System)
Function monotonically $(<10 \mathrm{~km}, 11-15 \mathrm{~km}$, IDE Chile (Ministry of $16-20 \mathrm{~km}, 21-25 \mathrm{~km} y>25 \mathrm{~km}$ ). Standarized National Assets) based on the average velocity walking of 5 $\mathrm{km} / \mathrm{hr}$ and bicycle $15 \mathrm{~km} / \mathrm{hr}$.

17. Use of urbanresidential soil

Function monotonically $(<10 \mathrm{~km}, 11-15 \mathrm{~km}$, $16-20 \mathrm{~km}, 21-25 \mathrm{~km}$ y $>25 \mathrm{~km})$. Standarized based on the average velocity walking of 5 $\mathrm{km} / \mathrm{hr}$ and bicycle $15 \mathrm{~km} / \mathrm{hr}$.

\begin{tabular}{|c|c|c|c|}
\hline \multirow{4}{*}{ Use of soils } & $\begin{array}{l}\text { 17. Use of urban- } \\
\text { residential soil }\end{array}$ & \multirow{4}{*}{$\begin{array}{l}\text { SINIA (National } \\
\text { Environmental } \\
\text { Information System) }\end{array}$} & \multirow{4}{*}{$\begin{array}{l}\text { Function monotonically }(<1 \mathrm{~km}, 2-4 \mathrm{~km}, 5-7 \\
\mathrm{km}, 8-10 \mathrm{~km} \text { y }>10 \mathrm{Km}) \text {. Expert criteria, } \\
\text { bibliographical revision. }\end{array}$} \\
\hline & 18. Use of agricultural soil & & \\
\hline & 19.Use of native forest soil & & \\
\hline & 20. Use of meadow soil & & \\
\hline Climate & $\begin{array}{l}\text { 21. Velocity of wind for } \\
\mathrm{H}=10\end{array}$ & $\begin{array}{l}\text { MDE Wind energy } \\
\text { portal (Ministry of } \\
\text { Energy) }\end{array}$ & $\begin{array}{l}\text { Function monotonically ( }>10 \mathrm{~m} / \mathrm{s}, 5-10 \mathrm{~m} / \mathrm{s} \text {, } \\
3-4 \mathrm{~m} / \mathrm{s}, 2-3 \mathrm{~m} / \mathrm{s} \text { y }<2 \mathrm{~m} / \mathrm{s}) \text {. Expert criteria and } \\
\text { bibliographical revision. Risks for soil } \\
\text { contamination and air environmental mining } \\
\text { liabilities. }\end{array}$ \\
\hline $\begin{array}{l}\text { Cost of } \\
\text { transport } \\
\text { (performance) } \\
\text { and stability }\end{array}$ & 22. Slope (\%) & $\begin{array}{l}\text { MDT (SRTM of } \\
\text { NASA) }\end{array}$ & $\begin{array}{l}\text { Linear curve: higher slope higher risk. }(>15 \% \\
, 15-10 \%, 10-5 \%, 5-3 \%, 3-0 \%)\end{array}$ \\
\hline
\end{tabular}

Table 2. Description and source of information of the variables for each factor considered in the MCE.

Tabla 2. Descripción y fuente de información de las variables para cada factor considerado en la evaluación multi - criterio.

sequently used as a basis for the development of the cellular automata.

In this study we have considered a global level of vulnerability of 5 (greater susceptibility) and the first nine factors obtained from the AHP as the most relevant, con- sidering a potential impact caused by MELs. The sum of the weights of these factors are 0.743 , then the value of .

The optimal locations defined by a $\mathrm{RI}<3.7$ (from the risk map) are evaluated. A grid is constructed, where each cell has an area of $1 \times 1 \mathrm{~km}^{2}$ (Figure 4a) 

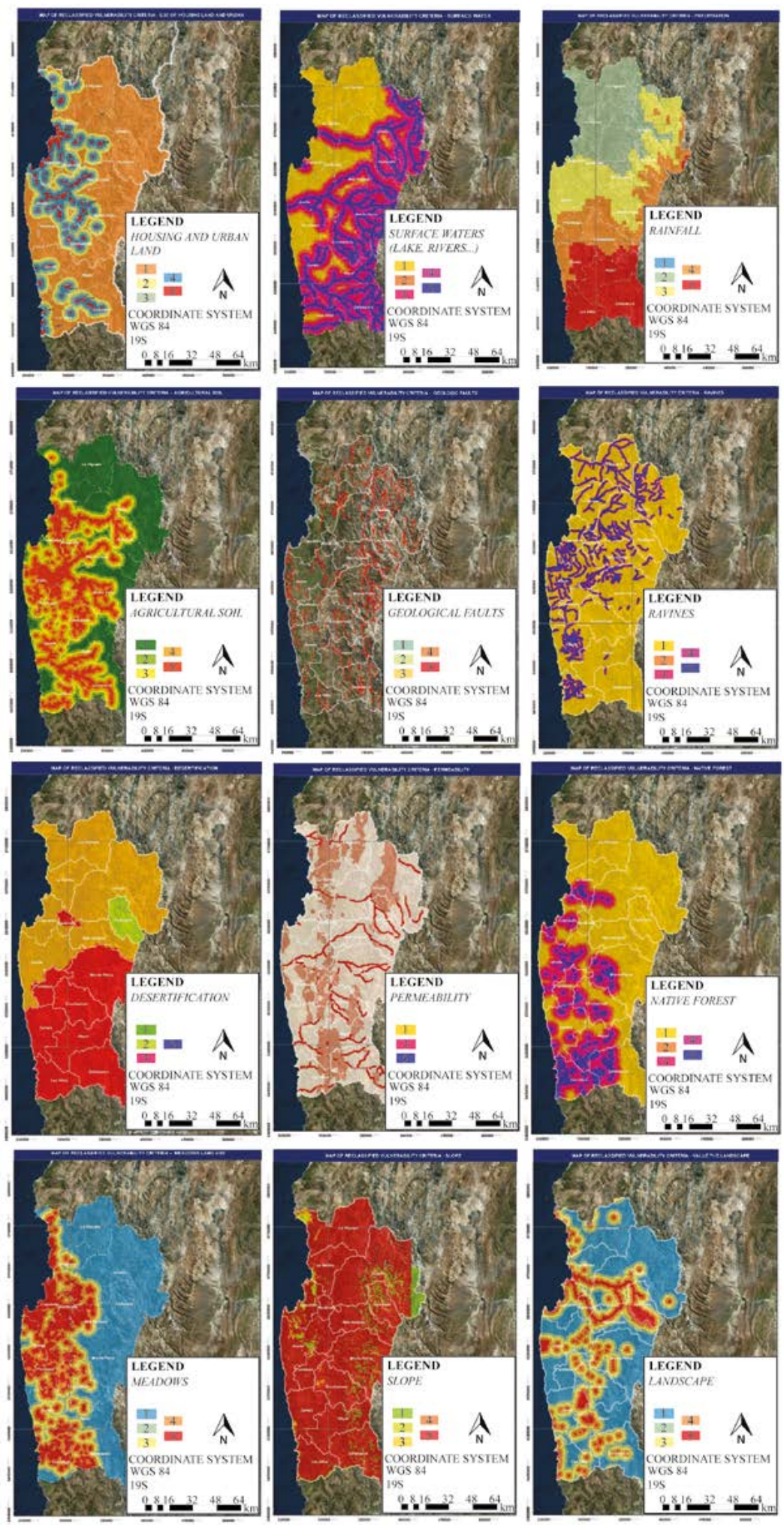

Figure 2. Factors analyzed in GIS, with reclassified ranges from 1 (lighter colours) to 5 (darker colours) in levels of vulnerability. From top to bottom and left to right: housing and urban land, surface waters, rainfall, agricultural soil, geological faults, ravines, desertification, permeability, native forest, meadows, slope (\%), landscape.

Figura 2. Factores analizados en SIG, con rangos reclasificado entre 1 (colores claros) a 5 (colores oscuros) en niveles de vulnerabilidad. De arriba abajo, de izquierda a derecha: Sectores urbanos, Aguas superficiales, Lluvia, Suelo de agricultura, Fallas geológicas, Quebradas, Desertificación, Permeabilidad, Bosque nativo, Prados, Pendiente, Paisaje. 


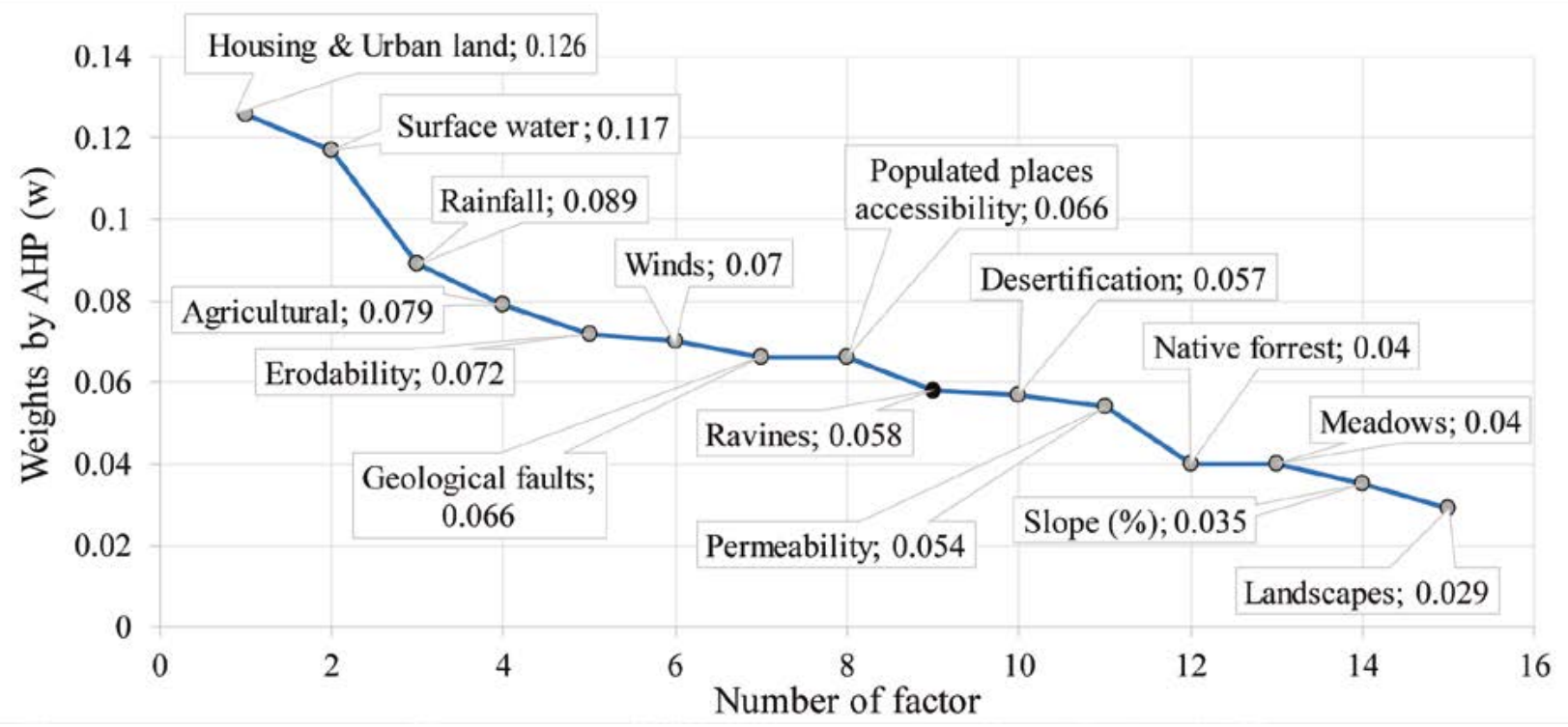

Figure 3. Weights obtained from the analytical hierarchy process (AHP). The first nine factors (black dot in the figure) were selected to calculate the Risk Index. The CR value obtained in the AHP was 0.04 , in agreement with the value proposed by Saaty (CR $<0.1$ ).

Figura 3. Pesos obtenidos del proceso de análisis jerárquico (PAJ). Los primeros nueve factores (punto negro en la figura) fueron elegidos para calcular el Índice de Riesgo. El valor de CR obtenido en el PAJ fue 0.04, concordando con el valor propuesto por Saaty (CR <0.1).

Subsequently, a specific point of open-pit mining is defined (blue dot in Fig. 4a), to which is assigned a rhythm of production of 5,000 ton/day, according to a median mining scale in Chile. Such production would generate 10,000 ton/day of waste, which would be deposited trapezoidal piles, within each cell of the grid covering all the available area of the $1 \times 1 \mathrm{~km}^{2}$ grid.

The growth of these piles with the interaction of the wind, in different height intervals, provokes the dispersal of fine material particles $(<10 \mathrm{~mm})$ toward surrounding areas of the territory (Fig. 4b). The parameters of the wind considered were the annual averages of direction and velocity of the year $\mathbf{2 0 1 0}$ for the zone in study.

The wind profile power law is often used to esti- mate the horizontal wind speed. The velocity $U_{2}$ at a height above the ground, $Z_{2}$, given the horizontal wind speed, $U_{1}$, at a reference height, $Z_{1}$, is calculated as (Irwin, 1979):

$$
U_{2}=U_{1}\left(\frac{Z_{2}}{Z_{1}}\right)^{p}
$$

where $p$ is related with the atmosphere stability. We considered a value of 0.25 , corresponding to a stable condition.

The reach radius of the dispersal of fine material particles, for the proposed mining dump site, was obtained considering the direction of winds predominant
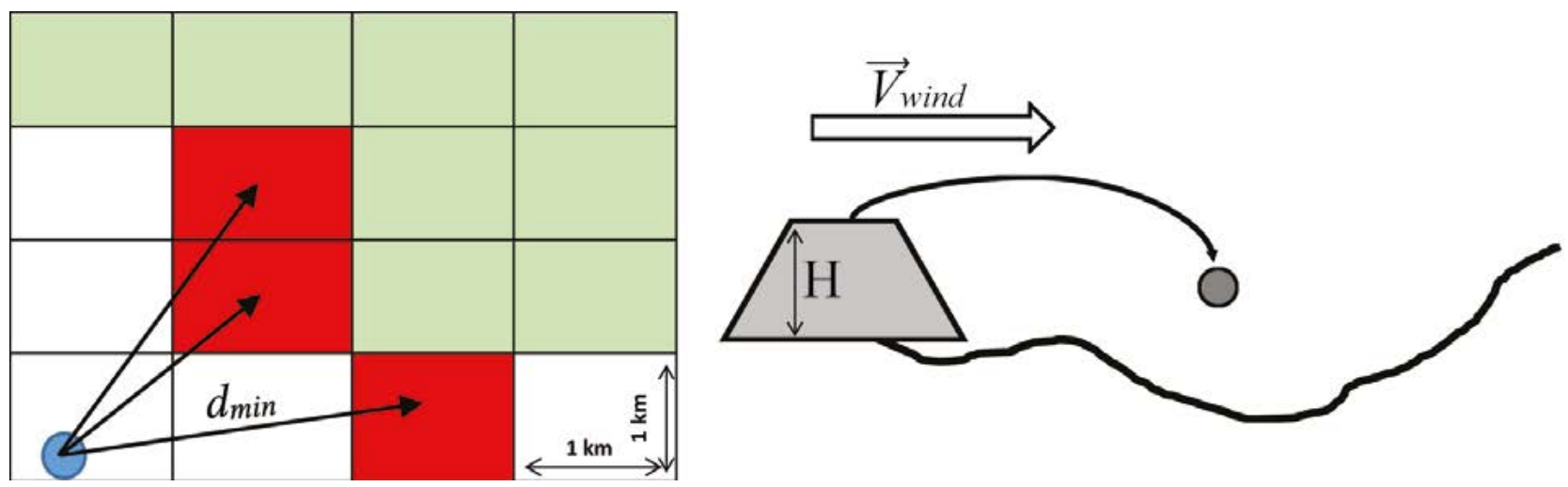

Figure 4. (a) Scheme representing the operation of the CA. White and green cells correspond to those cells with $\mathrm{RI} \geq 3.7$ and $\mathrm{RI}<3.7$ respectively. Red cells are those that, with $\mathrm{RI}<3.7$, were already occupied and were the nearest cell (dmin) to the location of the mine (blue dot); (b) Scheme of the model of dispersion of fine particulate material.

Figura 4. (a) Esquema representando la operación con autómatas celulares. Las celdas blancas y verdes corresponden a aquellas celdas con $R I \geq 3.7$ and $R I<3.7$ respectivamente. Las celdas rojas son aquellas que, con $R I<3.7$, ya fueron ocupadas y eran las celdas más cercanas (dmin) a la locación de la mina (punto azul); (b) Esquema del modelo de la dispersión de las partículas finas de material. 
in the zone, its velocities, the terrain level and the depositional velocity of the particle. Giardina and Buffa (2018) compared different methods for modelling dry deposition velocity of particles and proposed a new one. To keep it simple, and following those results, we considered a depositional velocity, $V d$, of $1 \mathrm{~m} / \mathrm{h}$.

Then, the simulation will iterate in each possible cell, until one of the following scenarios happens:

- The pollutant emitted by the waste dump falls in a cell with $\mathrm{RI} \geq 3.7$.

- A dump reached the maximum height of $120 \mathrm{~m}$ without the first point happening

The minimum wind velocity that we will consider for the particle that leaves the dump will be $5 \mathrm{~m} / \mathrm{s}$. This value corresponds to a gentle to moderate breeze on the Beaufort scale (Royal Metereological Society, 2018), capable of generating dust in the air.

Finally, some aspects were not considered for the behaviour of the particle:

- Effects of the atmospheric boundary layer and its associated vertical winds.

- Variations in temperature or any other variation in meteorological variables.

In this manner, we can form results which permit the ranking of optimal locations according to combinations of minimum distance dump-mine, maximum tonnage and lower risk, defining a logistic of an efficient distribution of sustainable waste, reasonable distances and viable and permissible locations, against the economic, ecological and social point of view.

\section{Results}

The following figures show the results obtained with the methodology previously explained.
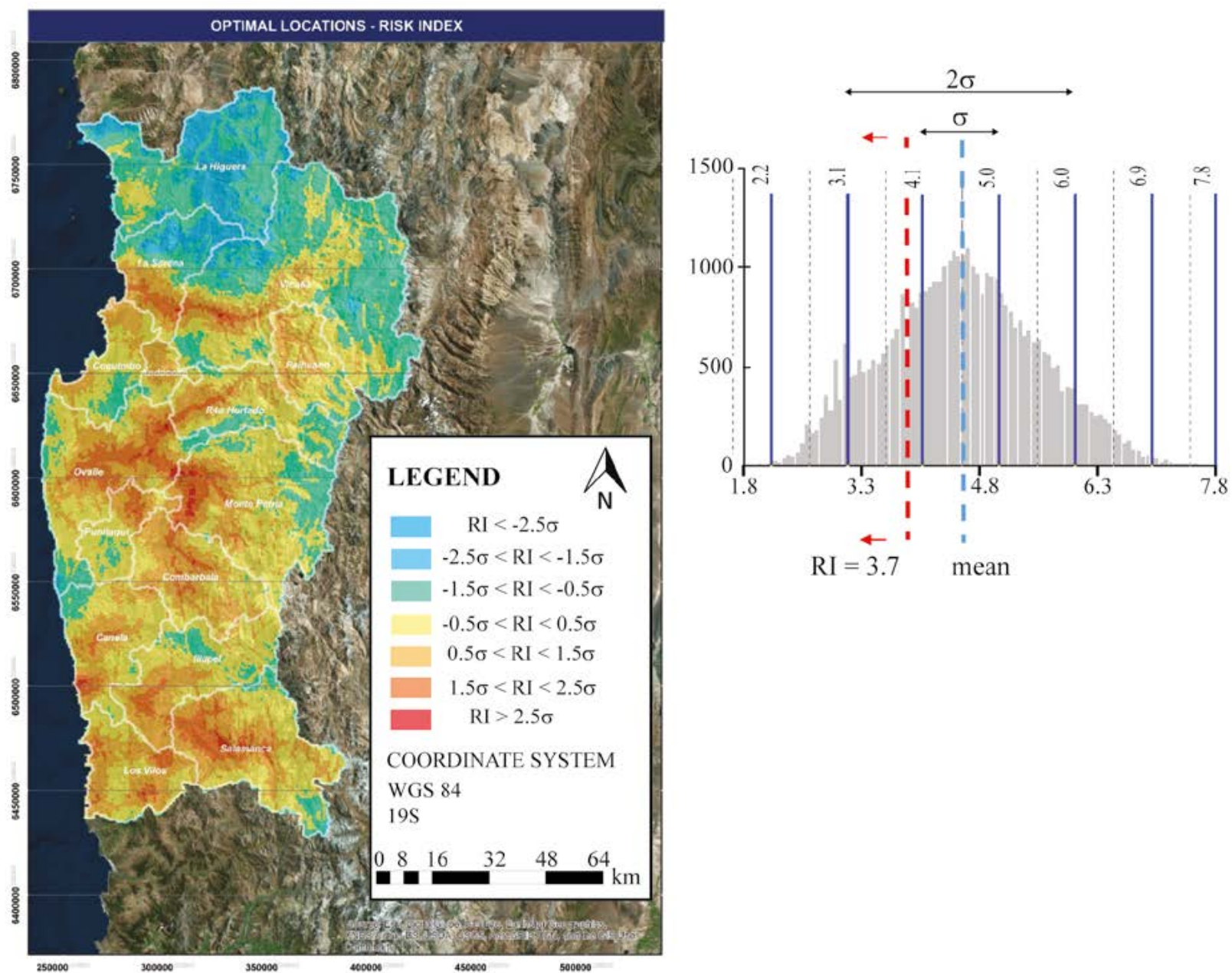

Figure 5. Result of the MCE. Optimal locations are shown in function of the Risk Index. The values less than -0.5 times the standard deviations are the zones of lower risk, complying with values of $\mathrm{Rl}<3.7$. In red, with values $>-0.5$ times the standard deviations, correspond to the areas of higher risk, versus a location of a massive mining waste.

Figura 5. Resultado de la evaluación multi - criterio. Cada línea azul en el histograma corresponde a +/- 0.5 desviaciones estándar. Las locaciones óptimas se muestran en función del Índice de Riesgo. Los valores menores a -0.5 veces la desviación estándar (líneas azules) son las zonas con menor riesgo, cumpliendo con los valores menores a 3.7. En rojo, con valores mayores a 0.5 veces la desviación estándar, corresponden a las áreas de mayor riesgo, contrario a la locación de desechos mineros masivos. 
Pérez, M., et al, 2021. Sustainable logistic plan for the dynamic distribution of massive mining waste..., 132 (4): $509-521$

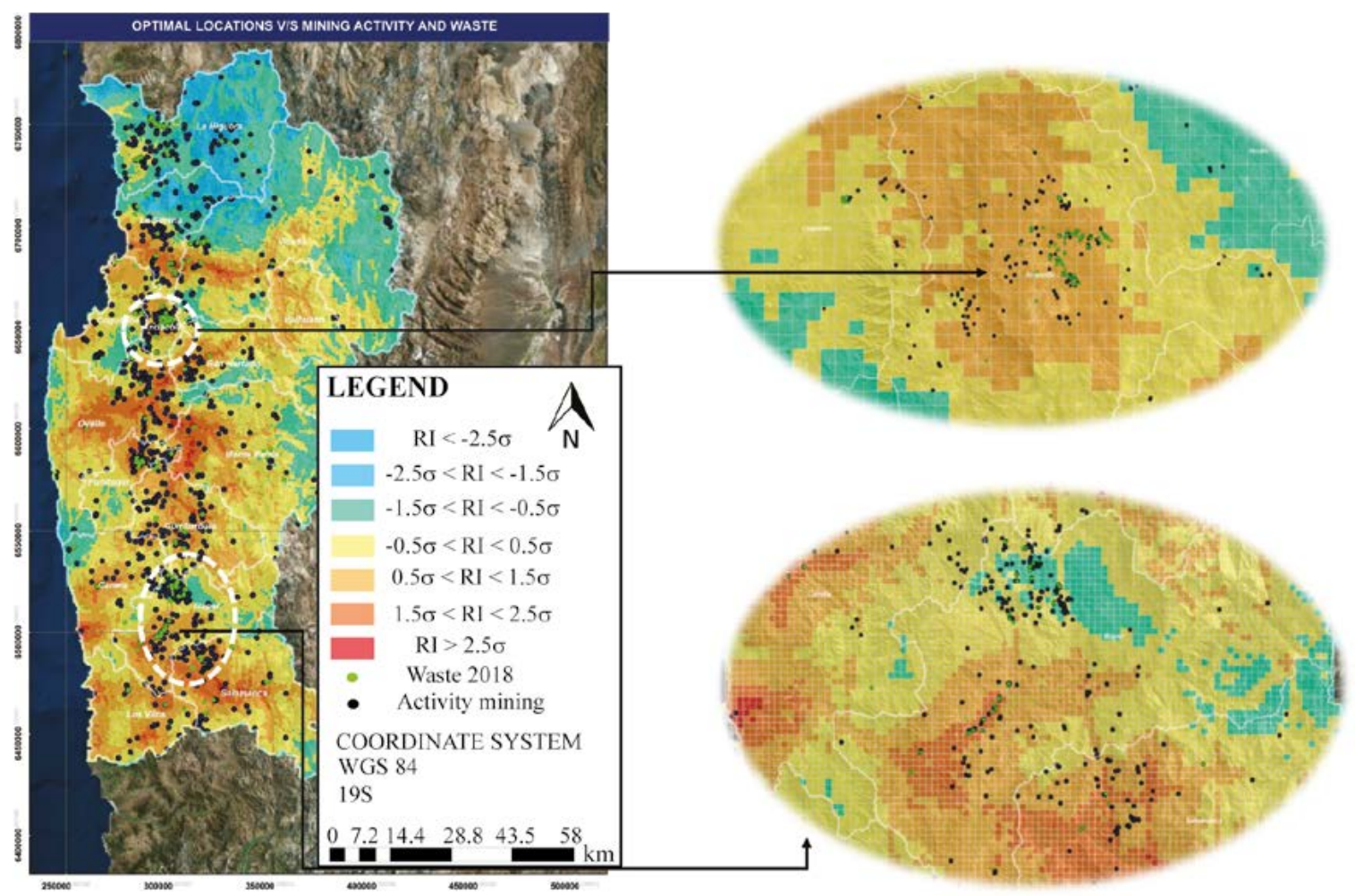

Figure 6. Levels of compatibility and incompatibility that exists between the modelled scenario (before the mining activity) versus the present scenario with an active mine operation.

Figura 6. Niveles de compatibilidad e incompatibilidad que existen entre el escenario modelado (antes de la actividad minera) contra el escenario actual con la operación minera activa.

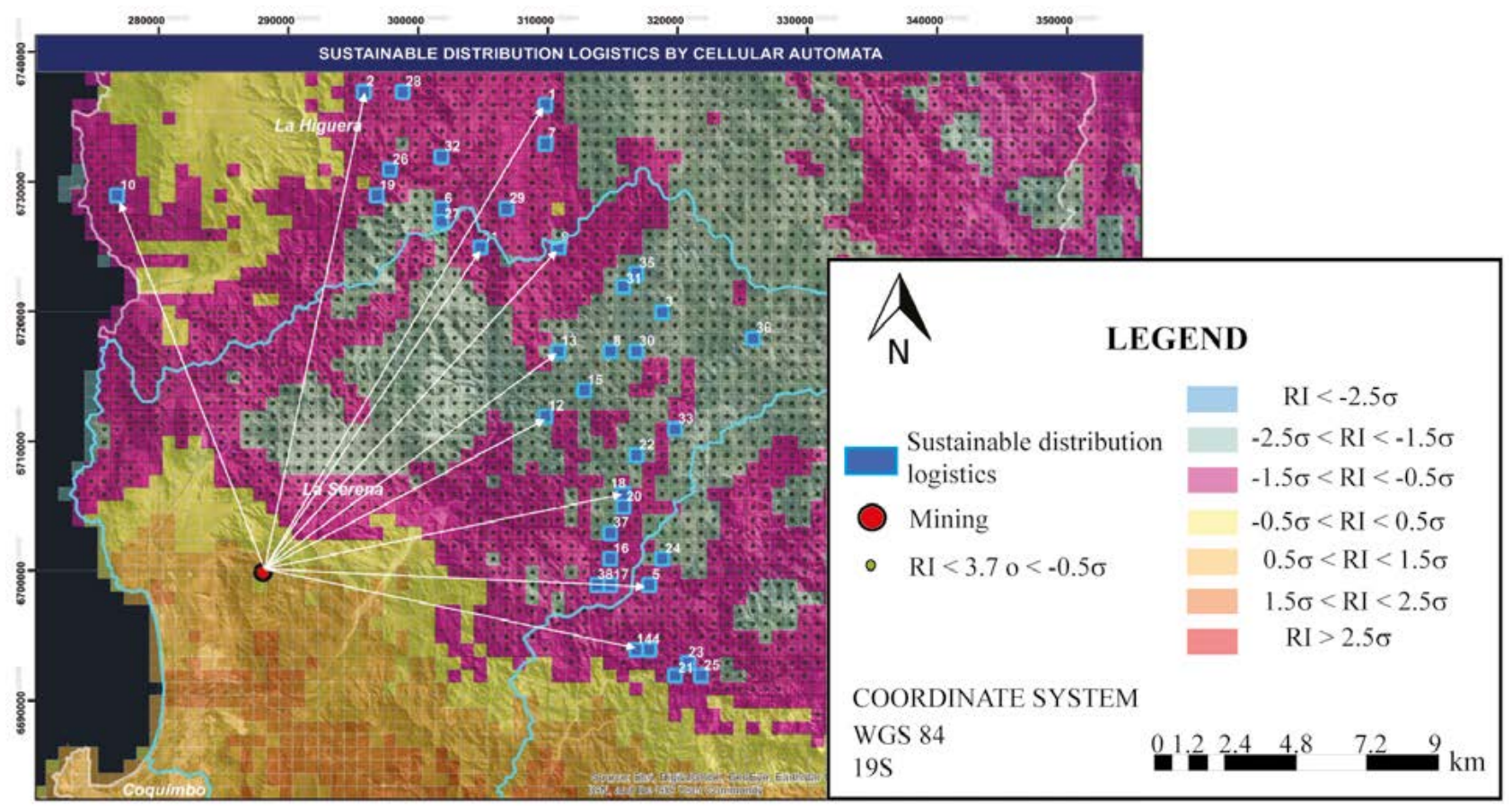

Figure 7.The results from CA programming. The red point corresponds to the location of the mine, in magenta the risk border cells, and the green cells are those with $\mathrm{RI}<3.7$. Cells in blue are those selected as optimal location in increasing order of impact (increasing RI value, see Fig. 8).

Figura 7. Resultados de la programación de autómatas celulares. El punto rojo corresponde a la locación de la mina, en magenta las celdas de riesgo límite y las celdas verdes son aquellas con $R I<3$.7. Las celdas en azul son aquellas seleccionadas como locaciones óptimas en orden creciente de impacto (aumento del valor de RI, ver Figura 8). 
Figure 5 shows the results from the MCE, with its respective statistical thresholds, which depict the areas of the lowest and highest impact defining the optimal locations for the waste.

A systemic analysis of the territory was considered, under a previous scenario of the mining operation, with the objective of conducting a comparative analysis contrary to the final result (Fig. 6). The activity in the region presents multiple mining waste deposits classified as environmental mining. The zones most affected in a direct manner are in Andacollo, Illapel and Salamanca. Indirectly this could also affect bigger cities such as La Serena and Coquimbo.

Figure 7 shows the results from CA programming, which have allowed us to define the sustainable logistic of distribution of the waste dump. Thirty seven cases where selected as optimal possibilities. The details of the first 14 cases are shown in Figure 8 . In this figure the first case generates the minimum impact, according to the value of the RI, which corresponds to the maximum value of the cell that the particulate material emitted by the dump reached in the simulation. A good capacity of waste is also achieved $\left(101,450,000 \mathrm{~m}^{3}\right)$ with a dump height of $101.45 \mathrm{~m}$, but at the expense of a larger distance between the mine and the dump. Nevertheless, the alternative 12 presents a minimum distance between the mine and the dump (which involves a lower transport cost), a similar volume capacity $\left(105,000,000 \mathrm{~m}^{3}\right)$ but with a higher impact $(R I=5.0)$. This level of volume is equivalent to 46 years of production of 10,000 tons of waste with density 1.6 ton $/ \mathrm{m}^{3}$.

It is important to mention that the ranking definition could vary if the technological advances aim to cover the waste as the pile grows, avoiding the propagation of particles, which would cause the risk index to decrease.
The results may vary according to the priorities of the decision maker, where the role of the state or the employer will be crucial, as well as the advance in the technology of depositing and processing the waste to achieve greater consistency (ideally solid as the filtered tail), to reach greater heights within a single waste area with high storage capacity and longer production time. In this way we propose a method that seeks to reduce the random deposit (without logic) or unique logic (minimum cost of transport), which has been used until now in Chilean mining.

\section{Discussions and Conclusions}

The integration of the used methods (cellular automatons, multi-criteria evaluation and geographical information systems), have allowed us to construct an effective methodology for massive mining waste management.

The selected optimal locations developed the activity under a harmonious ordinance with the territory agents, constituting a proposal that could facilitate the resolution of this complex territorial problem in a more correct way, with less difficulties and social complaints.

It is evident that this is a first approximation (best case scenario) to a very complex problem, where there are various parameters and criteria which can be calibrated in a more precise manner and variables which eventually could be included or measured with greater precision and level of update, which would make a more robust model.

The definitive decision of using one or various proposed locations requires detailed studies of each one of these locations, where decisions could include political opportunities, and the initial investment as the operational investment.

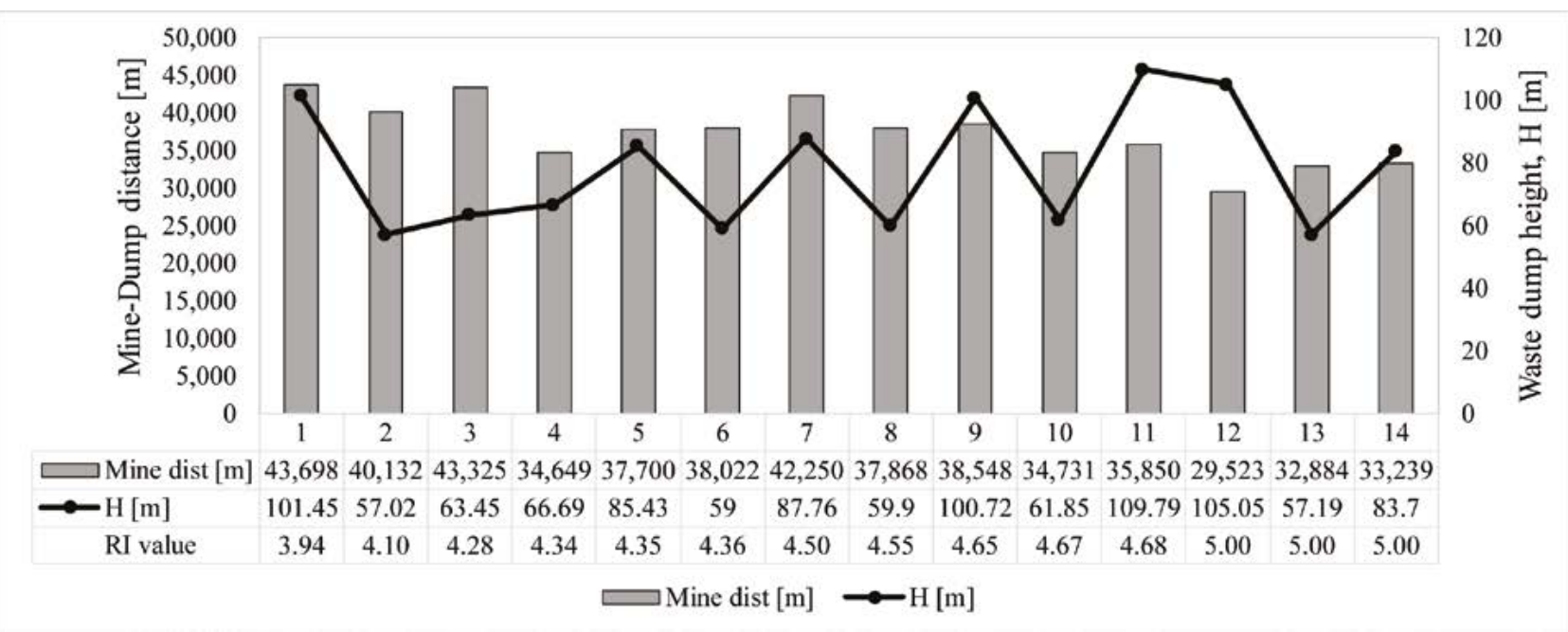

Figure 8. Distribution of the first 14 of 37 options, identifying the minimum impact value (minimum RI), maximum dump height reached and the distance between the mine and the waste dump.

Figura 8. Distribución de las primeras 14 de 37 opciones, identificando el valor de impacto mínimo (menor RI), altura de botadero máxima alcanzada y la distancia mina - botadero. 
The results of the hierarchical weights are consistent with the finality of the protection of factors of high importance in terms of eco-systemic, human, and hydrological resources, production areas (agricultural and meadow), and precipitation associated with risk of physical stability and environmental contamination.

Regarding the results in Figure 5, it is clear that it is important to analyse even the less optimal areas. The areas of the Pupio tideland and the Choapa river and the Caimanes of Los Pelambres mine are some of the most notable cases. The results qualify these territories as being completely inappropriate locations for waste. The same occurs with Andacollo where a significant degree of inconvenience exists for the mining operation of Carmen de Andacollo.

These incompatibilities are also present in other towns such as Illapel and Salamanca, coinciding with the future projects of the Tres Valles and Don Gabriel mines. The evaluated coincidences validate the model and give a potential alternative as an objective tool, for common use by the mining authorities and investors.

These results present various challenges for the development of technologically innovative methods, to find solutions that permit the mining production of the areas with the highest potential. The innovations should focus on technologies that mitigate the mining impact, contribute to the reduction of the waste produced, encourage ways of reutilization of the waste for other purposes and find new methods to deposit and transport waste that are competitive in costs.

Finally, our research underlines the idea that if epistemological foundations for sustaining the need for mining for humanity exist, as well as methodologies and technologies for their development under restrictive criteria against their impact and are proactive against the protection of the medium, sustainable mining is indeed a fact.

\section{Acknowledgments}

The authors acknowledge the Federico Santa María Technical University that has supported us through its Complementary Support Program for Research.

\section{References}

Adamatzky, A. 1994. Identification of cellular automata, Taylor \& Francis Ltd.

Barredo, B.J. 1996. Geographic Information System and multi-criteria evaluation in the territorial ordering. RA-MA Editorial, Madrid, 279 p.

Benavente, A. 2006. Predicción del crecimiento urbano mediante sistemas de información geográfica y modelos basados en autómatas celulares. GeoFocus, 6, 81-112.

Chang, N.B., Parvathinathan, G. and Breedenc J.B. 2008, Combining GIS with fuzzy multicriteria de- cision-making for landfill siting in a fast-growing urban region, Journal of Environmental Management, 87, 139-153.

Donevska, K., Gorsevski, P., Jovanovski, M. and Pesevsky, I. 2012. Regional non - hazardous landfill site selection by integrating fuzzy logic, AHP and geographic information systems, Environmental Earth Sciences, 67, 121 - 131. DOI 10.1007/s12665-0111485-y.

Echavarría, C. 2004. Transacciones complejas entre el potencial y lo viable, Procesos globales, serie Minería y Desarrollo Sustentable, Publisher: Iniciativa de Investigación sobre Políticas Mineras (IIPM) del International Development Research Centre (IDRC), Canadá, 2004, Volume 3.

Encina, V. and Pérez, M. 2016. Holistic model in sustainable mining: a paradigm to face the climate change. XXXVII National conference and XXII International conference of geography: geography for the human sustainable human development, Chile, $24 \mathrm{p}$.

Fundación Terram, 12/06/2019, https://www.terram.cl/2016/03/catastro-de-los-relaves-mineros-del-norte-de-chile-antofagasta/

Giardina, M. and Buffa, P. 2018. A new approach for modeling dry deposition velocity of particles. Atmospheric Environment, 180, 11-22.

Henríquez, C. and Qüense, J. 2010. Multi-criteria/Multi-Objective evaluation applied to land use/cover in Chillán watershed, FONDECYT Project. 17/05/2019, https://goo.gl/PW5WoV.

Infraestructura de Datos Espaciales (IDE), 12/06/2019, http://www.geoportal.cl/visorgeoportal/

Irwin, J. 1979. A theoretical variation of the wind profile power-law exponent as a function of surface roughness and stability. Atmospheric Environment, 13, 191-194.

Jiménez, A. and Posadas A.M. 2004. Sismicidad, entropía y autómatas celulares: patrones sísmicos de la Península Ibérica, Universidad de Almería servicio de publicaciones.

Royal Metereological Society, The Beaufort scale, how is wind speed measured?, 21/10/2019, https:// www.rmets.org/resource/beaufort-scale

Saaty, T. 1980. The analytic hierarchy process. McGraw - Hill, New York.

Saaty, T. 1990. How to make a decision: The Analytic Hierarchy Process, European Journal of Operational Research, 48, 9-26.

Siddiqui, M., Everett, J.M. and Vieux, B. E. 1996, Landfill siting using Geographic Information Systems: a demonstration, Journal Environmental Engineering, 122, 515-523.

United Nations, Report of the World Commission on Environment and Development, "Our common future," 07/06/2019, https://sustainabledevelopment. un.org/content/documents/5987our-common-future.pdf.

Recibido: julio 2020

Revisado: diciembre 2020

Aceptado: enero 2021

Publicado: diciembre 2021 
